\title{
Perspective
}

\section{Catechol-O-Methyltransferase (COMT): A Gene Contributing to Sex Differences in Brain Function, and to Sexual Dimorphism in the Predisposition to Psychiatric Disorders}

\author{
Paul J Harrison*,' and Elizabeth M Tunbridge' \\ 'Department of Psychiatry, Warneford Hospital, University of Oxford, Oxford, UK
}

\begin{abstract}
Sex differences in the genetic epidemiology and clinical features of psychiatric disorders are well recognized, but the individual genes contributing to these effects have rarely been identified. Catechol-O-methyltransferase (COMT), which metabolizes catechol compounds, notably dopamine, is a leading candidate. COMT enzyme activity, and the neurochemistry and behavior of COMT null mice, are both markedly sexually dimorphic. Genetic associations between COMT and various psychiatric phenotypes frequently show differences between men and women. Many of these differences are unconfirmed or minor, but some appear to be of reasonable

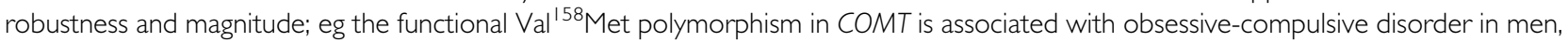
with anxiety phenotypes in women, and has a greater impact on cognitive function in boys than girls. Sex-specific effects of COMT are usually attributed to transcriptional regulation by estrogens; however, additional mechanisms are likely to be at least as important. Here we review the evidence for a sexually dimorphic influence of COMT upon psychiatric phenotypes, and discuss its potential basis. We conclude that despite the evidence being incomplete, and lacking a unifying explanation, there are accumulating and in places compelling data showing that COMT differentially impacts on brain function and dysfunction in men and women. Since sex differences in the genetic architecture of quantitative traits are the rule not the exception, we anticipate that additional evidence will emerge for sexual dimorphisms, not only in COMT but also in many other autosomal genes.

Neuropsychopharmacology (2008) 33, 3037-3045; doi: I0. I038/sj.npp. I30I543; published online 5 September 2007
\end{abstract}

Keywords: dopamine; gender; genotype; polymorphism; sexual dimorphism

Sex is an important factor in neuroscience (Cahill, 2006) and psychiatry (Cosgrove et al, 2007). Many parameters of brain function and structure vary between men and women (eg Gur et al, 1995; Murphy et al, 1996; De Courten-Myers, 1999; De Bellis et al, 2001; Goldstein et al, 2001; Preece and Cairns, 2003; De Vries, 2004), and most psychiatric disorders show sex differences in one or more variables including incidence, age at onset, clinical features, and outcome (eg Lensi et al, 1996; Tamminga, 1997; Piccinelli and Wilkinson, 2000; Aleman et al, 2003; Baron-Cohen et al, 2005). These dimorphisms are usually ascribed primarily to the influence of sex hormones (Collaer and Hines, 1995; Rubinow and Schmidt, 1996; Seeman, 1997; Kelly et al, 1999), as well as to the actions of sex chromosome genes (Vawter et al, 2004; Cutter et al, 2006; Davies and Wilkinson, 2006). Sex differences in epigenetic mechanisms, such as DNA methylation and chromatin modifications, predisposing to these phenotypes may also play a major role

*Correspondence: Professor PJ Harrison, Department of Psychiatry, Warneford Hospital, University of Oxford, Neurosciences Building, Oxford, Oxfordshire OX3 7JX, UK, Tel: + 441865 223730, Fax: + 44 I 865 25 I076, E-mail: paul.harrison@psych.ox.ac.uk

Received 28 March 2007; revised I 4 July 2007; accepted 24 July 2007
(Kaminsky et al, 2006). In addition, there is evidence that autosomal genes contribute to sex differences in the genetic predisposition to psychiatric phenotypes. For example, chromosomal loci implicated in the vulnerability to major depression (Holmans et al, 2004; Nash et al, 2004), neuroticism (Fullerton et al, 2003), obsessive-compulsive disorder (OCD; Nestadt et al, 2000), and autism (Stone et al, 2004) differ between men and women. Such differences occur against a background of a sex difference in heritability estimates for some disorders; eg the heritability of major depression is greater in women than in men (Kendler et al, 2006). These indications that there are differences in the genetic factors contributing to psychiatric phenotypes in men and women is consistent with the fact - not always appreciated - that the genetic architecture of many, perhaps most, human traits is sexually dimorphic (Weiss et al, 2006).

Despite this diverse evidence for sex differences in the genetic basis of many psychiatric disorders and related phenotypes, the identity of the contributing genes is largely unknown. While perusing the literature and conducting studies of Catechol-O-methyltransferase (COMT), we were struck by several lines of evidence that suggest it may be one such gene. Here we review these data, 
consider the possible mechanisms, and discuss the broader implications.

\section{CATECHOL-O-METHYLTRANSFERASE}

Recent reviews discuss in detail the neurobiological and psychiatric implications of COMT (Weinberger et al, 2001; Craddock et al, 2006; Tunbridge et al, 2006a), and its pharmacology (Mannisto and Kaakkola, 1999). Briefly, COMT is an $S$-adenosylmethionine-dependent methyltransferase enzyme that methylates catechol substrates, notably catecholamines and catechol estrogens. It exists in two forms, soluble (S-COMT) and membrane-bound (MB-COMT), arising from different translation start sites. These isoforms differ in their affinity and capacity for substrates; in contrast to other tissues, MB-COMT predominates in brain, likely reflecting its higher affinity for the catecholamine neurotransmitters. The psychiatric relevance of COMT arises primarily from its role in cortical dopamine metabolism, although with regard to the sex differences, its role in methylating catechol estrogens should be borne in mind (see below). The COMT gene is located on chromosome 22q11. It contains several single nucleotide polymorphisms (SNPs) of known or suspected functional significance, notably rs4680, a 472G/A substitution at codon 158 in MB-COMT (codon 108 in S-COMT) that encodes either valine (Val) or methionine (Met), referred to here as $\mathrm{Val}^{158}$ Met. This SNP influences the thermal stability and activity of COMT; the key study is that of Chen et al (2004), who found COMT activity in human prefrontal cortex to be $35-50 \%$ lower in $\mathrm{Met}^{158}$ homozygotes than in $\mathrm{Val}^{158}$ homozygotes; prior studies had found even larger genotype differences in erythrocyte COMT activity (Lachman et al, 1996). In consequence, dopamine signaling is likely to be enhanced in Met ${ }^{158}$ - compared to Val ${ }^{158}$-carrying individuals, consistent with pharmacological evidence (Tunbridge et al, 2004a). Following the landmark study of Egan et al (2001), a range of studies have shown that the $\mathrm{Val}^{158}$ Met allele has a small but significant impact on prefrontal cognitive performance and efficiency, with Met $^{158}$-carrying individuals performing better and/or more efficiently than $\mathrm{Val}^{158}$-carrying individuals (Barnett $e t$ al, 2007b). Conversely, the $\mathrm{Val}^{158}$ allele is associated with more 'flexible' cognitive responses (Bilder et al, 2004), especially during emotional processing (Smolka et al, 2005; Drabant et al, 2006). Apart from Val ${ }^{158}$ Met, other common COMT SNPs are noncoding (synonymous, intronic, or in the promoter or $3^{\prime}$-untranslated regions). As such, any functional impact they confer is presumably mediated by an effect on COMT expression; however, the evidence remains unclear (Bray et al, 2003; Chen et al, 2004; Tunbridge et al, 2004b; Dempster et al, 2006) and is likely complicated both by nonlinear interactions between the SNPs (Meyer-Lindenberg et al, 2006; Nackley et al, 2006), and by the range of molecular processes involved (Nackley et al, 2006). In any event, few studies that inform about sexual dimorphism and COMT have included any of these other SNPs, and hence it is $\mathrm{Val}^{158} \mathrm{Met}$ that is the major focus here.

\section{COMT AND SEXUAL DIMORPHISMS}

Catechol-O-methyltransferase exhibits sexual dimorphisms in the normal brain that set the scene for, and may contribute to, its differential involvement in psychiatric disorders in men and women. An important post-mortem study by Chen et al (2004), involving 118 subjects, showed COMT activity in prefrontal cortex to be $17 \%$ higher in men than women (independent of $\mathrm{Val}^{158} \mathrm{Met}$ and other SNPs), in agreement with earlier findings of $30 \%$ higher enzyme activity in men in liver (Boudikova et al, 1990) and also in most (Fahndrich et al, 1980; Floderus and Wetterberg, 1981; Philippu et al, 1981) but not all (Fitzgerald et al, 1980) studies of erythrocytes. It is not known at what stage in life the dimorphism in brain COMT activity manifests, since the sole developmental study was conducted almost entirely in men (Tunbridge et al, 2007a). Interestingly, the higher brain COMT activity in men occurs despite levels of COMT protein and mRNA being similar in both sexes (Bray et al, 2003; Chen et al, 2004; Tunbridge et al, 2004b) or higher in women (Dempster et al, 2006). This dissociation between expression and activity has implications for the likely mechanism underlying COMT sexual dimorphism, as discussed later.

The other main evidence for sexual dimorphism in normal COMT function comes from the COMT knockout mouse (Gogos et al, 1998). Tissue dopamine levels in the frontal cortex are increased almost threefold in male COMT- - - mice (and twofold in $+1-$ mice) compared to wild-type mice, confirming the importance of COMT in cortical dopamine metabolism; conversely, in female $C O M T+/-$ and $-/-$ mice, dopamine levels were unchanged. The lack of effect of COMT deletion on frontal cortex dopamine in female mice presumably reflects the existence of sex-specific compensatory mechanisms (such as a higher activity of dopamine or norepinephrine transporters), although this has not been determined. In contrast, female but not male COMT null mice showed greater anxiety compared to wild-type mice. Mechanistically, the basis for, and the relationship between, the maleonly neurochemical effect and the female-only behavioral phenotype, remains to be explained. Further studies in the COMT knockout mice, using cocaine, GBR 12909 (a dopamine transporter inhibitor), levodopa, or amphetamine, showed that some but not all neurochemical and behavioral responses to these pharmacological challenges are sex specific (Huotari et al, 2002a,b, 2004; see also O’Tuathaigh et al, 2007). For example, $d$-amphetamine administration affected dopamine metabolism equally in male and female knockout mice (Huotari et al, 2004), whereas hyperactivity in response to GBR 12909 was attenuated only in male mice (Huotari et al, 2002b).

A final COMT sexual dimorphism worthy of mention concerns allele frequencies. In 4014 Ashkenazi Jews (control subjects participating in a genetic association study of schizophrenia discussed below), Shifman et al (2002) found that the frequency of the $\mathrm{A}$ allele of the $3^{\prime}$-untranslated region SNP rs165599 was higher in women than men $(65 \mathrm{vs}$ $61 \%, p=0.0009)$; they state that a similar difference was seen in a second sample, giving a combined $p$-value of 0.00009 (see also Shifman et al, 2004). The authors speculate that the finding may be due to a reduced viability of female fetuses carrying this allele. However, to our knowledge, a sex difference in rs165599 allele frequency has not been replicated (eg Sweet et al, 2005; see also Molero et al, 2007) - albeit no other study has reported on such a large sample - and so its significance remains unclear. 


\section{SEXUALLY DIMORPHIC EFFECTS OF COMT GENOTYPE ON PSYCHIATRIC DISORDERS AND RELATED PHENOTYPES}

Table 1 is an extensive but not exhaustive list of the studies that have reported a sex difference in the impact of COMT genotype on a psychiatric phenotype. The studies vary in the robustness and plausibility of the finding with regard to sex, in several respects. Few have been statistically convincing, eg by demonstrating a sex-by-genotype interaction (eg Kates et al, 2006; Lang et al, 2007). Many studies simply found an association that reached significance in one sex but not in the other, without demonstrating an interaction between sex and genotype (eg Enoch et al, 2006), an approach further compromised by the fact that the nonsignificant sex often had a smaller sample size and less power than did the significant one (eg Nolan et al, 2000; Ono et al, 2004; Stein et al, 2005). Other studies discuss sex-related effects despite reporting a nonsignificant sex-by-genotype interaction (eg Olsson et al, 2005; Zinkstok et al, 2006), while a final category of studies, not included in the table, provide only trend-level findings of sex-related effects of COMT genotype (eg Eley et al, 2003; Sazci et al, 2004; Woo et al, 2004). A further consideration is that some phenotypic associations with a COMT allele are in the opposite direction in the two sexes, rather than just being limited to one sex (eg Dauvilliers et al, 2001; Rybakowski et al, 2006); such findings may be correct, but in the absence of a prior hypothesis, or replication, may well be false positives.

These issues and limitations mean that most of the studies in Table 1 are merely suggestive and do not, in isolation, provide convincing evidence that COMT genetic variation has a sexually dimorphic influence on the phenotype in question. Nevertheless, the number of studies showing at least some evidence for sexual dimorphisms is intriguing, especially as among the studies are several more striking and robust findings of this kind. It is the latter results that we focus upon here.

Karayiorgou et al (1997) were the first to report a sex difference in the role of COMT in the genetic predisposition to a psychiatric disorder. They showed that the low-activity $\left(\mathrm{Met}^{158}\right)$ allele was associated with OCD in men, but not in women. The finding was replicated in a family-based study (Karayiorgou et al, 1999), and in three out of four subsequent case control studies (Poyurovsky et al, 2005; Denys et al, 2006; Pooley et al, 2007). The sex-selective effect of COMT in OCD was confirmed in a meta-analysis (Pooley et al, 2007); the odds ratio associated with the Met $^{158}$ allele in men was $1.88(p<0.001)$, with no effect in women (odds ratio $0.98, p=0.83$ ), and with a significant sex difference between the odds ratios $(p<0.0001)$. The COMT OCD data are arguably the clearest evidence to date for a sexually dimorphic autosomal genetic association with a psychiatric disorder.

Another demonstration of a sexually dimorphic role for COMT is that of Barnett et al (2007a), who genotyped the $\mathrm{Val}^{158}$ Met SNP in over 5000 participants in a longitudinal study of child development, and in whom a range of cognitive tests, including IQ, attention, and working memory had been conducted between ages 8 and 10. The $\mathrm{Met}^{158}$ allele was found to be associated with better function in several domains, with these effects greater in, or limited to, boys. For example, in boys, Met ${ }^{158}$ homozygotes had a verbal IQ 3 points higher than $\mathrm{Val}^{158}$ homozygotes, whereas the difference in girls was less than 1 point. The data also showed that the COMT effect on verbal IQ was greater in pubertal than prepubertal boys (increasing to a 10 -point difference between homozygote groups), suggesting that its influence increases with sexual maturation. An interaction with developmental stage is consistent with COMT $\mathrm{Val}^{158} \mathrm{Met}$ data in a longitudinal study of velo-cardio-facial syndrome (VCFS or 22q11 hemideletion syndrome, in which one copy of COMT is deleted; Gothelf et al, 2005). There are also significant maturational increases in COMT expression and activity in prefrontal cortex, albeit these occur postadolescence not peri-pubertally (Tunbridge et al, 2007a). Kates et al (2006) also studied children with VCFS. Their finding, though in a small sample, is noteworthy because it concerns brain structure, and also because the dimorphism is statistically robust-a sex-by-genotype interaction $(p<0.001)$, with an opposing effect of $\mathrm{Val}^{158} \mathrm{Met}$ allele on frontal cortical volumes in boys and girls. These data, together with those of Zinkstok et al (2006), raise the possibility of a complex interaction between COMT genotype, sex, brain structure, and development.

Shifman et al (2002) reported that homozygosity for the G allele at rs165599 of COMT was strongly associated with schizophrenia in women $\left(p=6.8 \times 10^{-6}\right)$ but not in men $(p=0.09)$, with the sex difference in genotype effect being significant $(p<0.01)$. The authors concluded that there may be a sex-specific genetic component to schizophrenia, while acknowledging that twin studies had not predicted this. Moreover, a sex difference in the genetic association with schizophrenia was not present for the other COMT SNPs they analyzed, nor was it observed for haplotypes (that included rs165599), and, as noted by Craddock et al (2006), it was driven by the dimorphic allele frequency in the control group mentioned above. Hence, despite the statistical significance, the result remains difficult to interpret vis-à-vis schizophrenia, and in need of replication, especially as Sazci et al (2004) reported a female-predominant association (of Met ${ }^{158}$ ) with schizophrenia, and the meta-analyses of COMT $\mathrm{Val}^{158} \mathrm{Met}$ with schizophrenia find no sex effect (Glatt et al, 2003; Fan et al, 2005).

A sex-by-genotype interaction $(p<0.0005)$ was seen by Lang et al (2007) who showed that the $\mathrm{Val}^{158}$ allele was associated with the personality trait of sensation-seeking in women. This finding is the latest in a line of studies that show relationships between COMT genotype and personality traits in women but not in men. In particular, anxietyrelated phenotypes (such as harm avoidance or neuroticism) have been repeatedly (though often weakly) associated in women with the $\mathrm{Met}^{158}$ allele (Eley et al, 2003; Enoch et al, 2003; Olsson et al, 2005; Stein et al, 2005), with similar findings in anxiety disorder (Domschke et al, 2004; Woo et al, 2004; Rothe et al, 2006). A recent meta-analysis of the panic disorder studies (Domschke et al, 2007) confirmed this sex difference, but also revealed an additional complexity, in that the relationship interacted with ethnicity such that panic disorder was associated with the $\mathrm{Met}^{158}$ allele in Caucasian women but with the $\mathrm{Val}^{158}$ allele in Asian women. The latter result is consistent with that of Kim et al (2006), who showed a $\mathrm{Val}^{158}$ association with harm avoidance in 
Table I Chronological List of Studies Reporting Sexually Dimorphic Effects of COMT Genotype on Psychiatric Disorders and Allied Phenotypes ${ }^{a}$

\begin{tabular}{|c|c|c|c|}
\hline Authors & Phenotype/parameter & $\begin{array}{l}\text { Males/ } \\
\text { females }\end{array}$ & Finding related to sex \\
\hline Karayiorgou et al, $1997^{b}$ & OCD & $117 / 104$ & Met $^{158}$ allele associated in men $(p=0.0002)$ not women $(p=0.066)$ \\
\hline Nolan et al, 2000 & $\begin{array}{l}\text { Suicide attempts in } \\
\text { schizophrenia }\end{array}$ & $|17 / 3|$ & Met $^{158}$ allele associated in men $(p=0.028)$ not women $(p>0.5)$ \\
\hline Dauvilliers et al, 200। & Sleep latency in narcolepsy & $59 / 38$ & Longer latency associated with $\mathrm{Met}^{158}$ allele in men, $\mathrm{Val}^{158}$ allele in women \\
\hline Shifman et al, $2002^{b}$ & Schizophrenia & $3980 / 1643$ & $\begin{array}{l}\text { G allele of rs } 165599 \text { associated in women }(p<0.00001) \text { not men }(p=0.1) \text {. } \\
\text { Sex difference } p=0.01\end{array}$ \\
\hline Enoch et al, 2003 & Harm avoidance & $|60 / 24|$ & Met $^{158}$ homozygosity associated in women $(p<0.03)$ not men $(p>0.79)$ \\
\hline Domschke et al, 2004 & Panic disorder & $82 / 148$ & $\mathrm{Val}^{158}$ allele associated in women $(p=0.01)$ not men $(p=1.0)$ \\
\hline Ono et al, 2004 & Suicide & $|12 / 5|$ & $\left.V_{a}\right|^{158}$ homozygosity protective in men $(p=0.016)$ not women $(p=0.96)$ \\
\hline Olsson et al, 2005 & Persistent episodic anxiety & $340 / 473$ & $\begin{array}{l}\text { Met }{ }^{158} \text { homozygosity associated in women }(p=0.02) \text { not men }(p=0.38) \text {. No } \\
\text { genotype } \times \text { sex interaction }\end{array}$ \\
\hline Poyurovsky et al, 2005 & OCD & $109 /|4|$ & Met $^{158}$ allele associated in men $(p=0.029)$ not women $(p=0.78)$ \\
\hline Stein et al, 2005 & Low extraversion & $154 / 343^{c}$ & Met $^{158}$ homozygosity associated in women $(p=0.001)$ not men $(p=0.6)$ \\
\hline Sweet et al, 2005 & $\begin{array}{l}\text { Psychosis in Alzheimer's } \\
\text { disease }\end{array}$ & $130 / 243^{c}$ & $\left.V_{a}\right|^{158}$ allele associated in women $(p=0.005)$ not men $(p=0.383)$ \\
\hline Kates et al, $2006^{b}$ & $\begin{array}{l}\text { Dorsal and orbital frontal } \\
\text { volumes }\end{array}$ & $25 / 26$ & Opposite effects in boys and girls with VCFS. Sex $\times$ genotype interaction $(p<0.001)$ \\
\hline Beuten et al, $2006^{b}$ & Nicotine dependence & $668^{d} / 1369^{c, d}$ & Met $^{158}$ allele associated in women. Sex $\times$ genotype interactions $(0.006<p<0.02)$ \\
\hline Denys et al, 2006 & OCD & $135 / 170$ & Met $^{158}$ allele associated in men $(p=0.036)$ not women $(p=0.23)$ \\
\hline Enoch et al, 2006 & Alcoholism and smoking & $|4| / 20 \mid$ & $\mathrm{Val}^{158}$ allele associated in women $(p=0.01 \mathrm{I})$ not men $(p=0.186)$ \\
\hline Kim et al, 2006 & Harm avoidance & $138 / 148$ & $\mathrm{Val}^{158}$ allele associated in women $(p=0.003)$ not men $(p=0.36)$ \\
\hline O'Hara et al, 2006 & Delayed verbal recall tests & $62 \% / 101^{\mathrm{e}}$ & $\begin{array}{l}V_{a}{ }^{158} \text { allele associated with 8-point WMS-R advantage in men. Sex } \times \text { genotype } \\
\text { interaction on BNT }\end{array}$ \\
\hline Rothe et al, 2006 & Panic disorder & $60 / 118^{d}$ & $\mathrm{Val}^{158}$ allele associated in women $(p=0.008)$ not men $(p=0.272)$ \\
\hline Rybakowski et al, 2006 & WCST in schizophrenia & $43 / 36$ & $\begin{array}{l}V_{a l}^{158} \text { homozygosity associated with fewer errors by men }(p=0.044) \text {, more errors } \\
\text { by women }(p=0.042)\end{array}$ \\
\hline Zinkstok et al, 2006 & $\begin{array}{l}\text { Gray and white matter } \\
\text { volumes }\end{array}$ & $57 / 97$ & Aging effects related to genotype in women only. No genotype $x$ sex interactions \\
\hline Barnett et al, 2007ab & $\mathrm{IQ}$ and executive function & $2650^{\mathrm{f}, \mathrm{g}} / 2650^{\mathrm{f}, \mathrm{g}}$ & Effects in boys only. Genotype $\times$ sex interactions on attention and verbal IQ \\
\hline Domschke et al, $2007^{b}$ & Panic disorder & $209 / 319$ & Meta-analysis. Association in women only: Val allele in Caucasians, Met allele in Asians \\
\hline Lang et al, 2007b & Sensation-seeking & $214 / 218$ & $\begin{array}{l}\left.V_{a}\right|^{158} \text { homozygosity associated in women }(p>0.005) \text { not men }{ }^{h} \text {. Sex } \times \text { genotype } \\
\text { interaction }(p=0.005)\end{array}$ \\
\hline Pooley et al, 2007b & OCD & $580 / 718$ & $\begin{array}{l}\text { Meta-analysis. Met }{ }^{158} \text { allele associated in men }(p=0.001) \text { not women }(p=0.83) \text {. } \\
\text { Sex difference } p=0.0001\end{array}$ \\
\hline
\end{tabular}

Abbreviations: BNT, Boston Naming Test; OCD, obsessive-compulsive disorder; IQ, intelligence quotient; VCFS, velo-cardio-facial syndrome (22q। I deletion syndrome); WCST: Wisconsin Card Sorting Test; WMS-R, Wechsler Memory Scale (Revised).

${ }^{a}$ All findings relate to $\mathrm{Val}^{158}$ Met polymorphism except where stated.

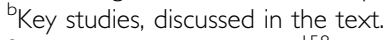

CHaplotypes containing Val ${ }^{158}$ Met were also studied.

${ }^{d}$ Calculated from their Table I.

eElderly adults.

fRepresentative number; exact sample size differed between tests.

${ }^{8}$ Children.

hp-value not stated.

Korean women. Two main explanations come to mind for the genotype-by-ethnicity interaction. First, given that the resulting subgroups are quite small and the $p$-values modest ( $p=0.04$ in Caucasians, $p=0.02$ in Asians; Domschke et al, 2007), the findings may be false positives. Second, if true, the finding may relate to ethnic differences in the genetic background of the $\mathrm{Val}^{158}$ Met polymorphism, such that the opposing allelic associations with panic disorder are both genuine (Lin et al, 2007).
Parenthetically, the data reviewed here show that the $\mathrm{Met}^{158}$ allele is associated with anxiety phenotypes in (Caucasian) women but with OCD - usually considered to be a type of anxiety disorder - in men. One interpretation is that $\mathrm{Met}^{158}$ is a risk factor for a predisposition to anxiety in both sexes, but that this manifests itself as different anxiety phenotypes in men and women because of other influences that are themselves sexually dimorphic, whether genetic, epigenetic, or environmental in origin. 
MECHANISMS OF SEXUAL DIMORPHISM IN COMT EFFECTS AND ASSOCIATIONS

Estrogens are usually implicated to explain the sex differences related to COMT. Contemporary interest can be traced to the work of Xie et al (1999), although many years previously Axelrod had reported that 17- $\beta$-estradiol (E2) administration decreased COMT activity in rat liver (Cohn and Axelrod, 1971). Xie et al (1999) showed that there are two estrogen response elements in the COMT promoter, and that E2 at physiological concentrations inhibits COMT mRNA expression in cells expressing estrogen receptors but not in those which do not. The same group later showed that the estrogen-mediated decrease in COMT mRNA was accompanied by a proportional decrease in COMT immunoreactivity and activity (Jiang et al, 2003). This inhibitory regulation by estrogens is consistent not only with the normal sex differences in COMT activity noted above, but with evidence that women with high estrogen states (eg on the combined oral contraceptive, or in the third trimester of pregnancy) have higher COMT activity than other women (Briggs and Briggs, 1973). In postmenopausal women, estrogen levels fall dramatically, to substantially below that of men of the same age (Bjornerem et al, 2004); it would be of interest to know if sexual dimorphisms in COMT activity (or its genetic associations) present in younger adults are lost or reversed in the elderly.

Complementing the estrogenic regulation of COMT, COMT plays an important role metabolizing catechol estrogens and thereby lowering levels of these potential carcinogens (Creveling, 2003). Notably, there is both in vivo (Worda et al, 2003) and in vitro (Dawling et al, 2001; but see Goodman et al, 2002) evidence that the Val ${ }^{158}$ Met SNP influences this pathway, with greater E2 metabolism in those with the high-activity $\mathrm{Val}^{158}$ allele; this may also explain the associations reported in some studies between the COMT $\mathrm{Met}^{158}$ allele and estrogenic cancers (see Goodman et al, 2002). These reciprocal, and partly genotype-influenced, interactions between COMT and estrogens may both be relevant to the question of sexual dimorphism: COMT genotype may modulate the role that estrogens play in brain function and dysfunction (Seeman, 1997), while estrogens affect COMT activity and its pathophysiological sequelae by virtue of their influence on COMT gene expression.

Despite the focus on estrogenic regulation of COMT gene expression, it is probably only a partial explanation for COMT sexual dimorphisms. Cohn and Axelrod (1971) found that E2 did not affect rat brain COMT activity despite its robust downregulation in the liver, and Jiang et al (2003) found estrogenic regulation of COMT in a breast cancer cell line but not in a glioblastoma cell line, again suggesting that this relationship may not pertain in the brain. The suggestion that estrogenic regulation of COMT may be less important in the brain than in the periphery is supported by several recent human brain studies showing that COMT activity is higher in men (Chen et al, 2004) even though women express COMT at the same (Tunbridge et al, 2004b; Chen et al, 2004) or higher (Dempster et al, 2006) levels. Hence, for a given level of COMT expression, COMT activity in the male brain is higher than it is in females, and therefore the sexual dimorphism cannot be explained by transcriptional regulation. This fact also bears upon potential explanations for sexual dimorphism in COMT based upon epigenetic regulation (Kaminsky et al, 2006); in any event, there is no evidence for a sex difference in COMT methylation status (Abdolmaleky et al, 2006). Furthermore, the finding that COMT protein and activity levels rise considerably in men between the third and fifth decade of life (Tunbridge et al, 2007a), despite steady estradiol levels across this period (Bjornerem et al, 2004) emphasizes that estrogens are not the only factor responsible for regulating COMT in the brain.

The basis for a sex difference in COMT activity without an accompanying difference in COMT abundance is unknown. It may be that the discrepancy is in fact spurious, since localized or phasic sex differences in mRNA or protein abundance in brain - eg in specific cell types, or in relation to menstrual cycle-have not been ruled out. However, the fact that a robust sex difference in COMT enzyme activity was seen with no hint of a sex difference in COMT protein measured in the same samples (Chen et al, 2004), suggests that it is genuine. As such, one possibility is that it reflects a sex difference in the relative abundance of novel mRNA (Tunbridge et al, 2007b) or protein (Tunbridge et al, 2006b) isoforms of COMT, which might differ in their enzyme activity and would not affect the amount of total COMT transcript or protein. Or, there could be a sex difference in the abundance of cofactors, endogenous inhibitors (eg S-adenosylhomocysteine; Zhu, 2002), or interacting proteins that modulate COMT activity.

Broadening the perspective, sexual dimorphisms in COMT occur against a background of sex differences in biochemical pathways, not only of the catechol estrogens, but also pertaining to dopamine, and the interactions between them (Morissette and Di Paolo, 1993; Becker, 1999; Andersen and Teicher, 2000; Carroll et al, 2004). For example, compared with men, women have higher striatal $\left[{ }^{18} \mathrm{~F}\right]$ fluorodopa uptake, suggestive of greater presynaptic dopamine synthesis (Laakso et al, 2002), and a lower D2 receptor affinity (Pohjalainen et al, 1998) which the authors hypothesized reflects their higher dopamine levels. Women also have lower amphetamine-stimulated dopamine release (Munro et al, 2006), and a greater dopamine transporter uptake (Mozley et al, 2001). Thus, compared with men, women appear to have elevated basal, but decreased stimulated, striatal dopamine levels. However, estrogenic state (eg phase of menstrual cycle) has not been fully taken into account and may be a significant confounder: rodent studies have shown marked fluctuations in multiple dopaminergic parameters in the striatum across the estrus cycle (Jori and Cecchetti, 1973; Favis et al, 1977; Crowley et al, 1978; Fernandez-Ruiz et al, 1991; Morissette and Di Paolo, 1993; Xiao and Becker, 1994). Sex differences in dopamine function are less well studied outside the striatum, in cortical regions wherein COMT is likely to play its major role (Karoum et al, 1994; Gogos et al, 1998). Cortical tissue dopamine concentrations are similar in men and women (Robinson et al, 1977), although women may have a higher extrastriatal D2 receptor-binding potential (Kaasinen et al, 2001). In summary, there are diverse data indicating sex differences in central dopaminergic parameters (see Cosgrove et al, 2007). However, it is not clear what their net effect is upon the dopamine system in men compared to women, nor how the dopaminergic sexual 
dimorphisms impinge upon the inverted U-shaped relationship between dopamine activity and prefrontal function (Goldman-Rakic et al, 2000) nor the modulatory effect that COMT has upon this relationship (Mattay et al, 2003; Tunbridge et al, 2006a; Williams-Gray et al, 2007).

\section{CONCLUSIONS}

Genetic epidemiological and other studies show that sex differences in the genetic architecture of many human traits, and of psychiatric disorders, are common. There is also a substantial literature attesting to male-female differences across many domains of brain function, structure, and development. The data reviewed here suggest that COMT is one of the genes that contribute to these sexual dimorphisms. As well as a difference in COMT enzyme activity between men and women, there is evidence that the involvement of COMT in predisposition to OCD and anxiety phenotypes is sex specific, and weaker evidence for sex differences in its roles in several other phenotypes.

Not all COMT genotypic associations are demonstrably sexually dimorphic; eg on any risk for schizophrenia that it confers (Glatt et al, 2003; Fan et al, 2005), or its influence on Wisconsin Card Sort Test performance (Barnett et al, 2007b) and on homocysteine metabolism (Tunbridge et al, 2007c). Neither is COMT the only autosomal gene for which sexually dimorphic genetic associations with psychiatric phenotypes have been reported; eg HTR2A with OCD in women (Enoch et al, 2001), MTHFR with schizophrenia in men (Sazci et al, 2005; Kempisty et al, 2006), and ACVII with depression in women (Hines et al, 2006). However, the data do appear more extensive, and in places statistically more convincing, for COMT than for any other autosomal gene we could determine, especially as the findings are complemented by the sexual dimorphism in COMT activity and by a plausible, if incomplete, mechanistic explanation in terms of estrogenic regulation. As such, COMT may well contribute to the genetic basis for sexual dimorphisms in human brain, behavior, and its disorders. However, it is clearly but one of many genes acting in this way, and in isolation explains only a tiny proportion of the variance. Future studies are needed not only to establish the range and magnitude of the COMTrelated sexual dimorphisms, but also to identify other genes, their epistatic and gene-environment interactions, and the underlying biological mechanisms.

\section{ACKNOWLEDGEMENTS}

We thank Daniel Weinberger for fruitful discussions and collaborations. Valerie West kindly provided secretarial assistance. We apologize to the authors of relevant studies that we have inadvertently omitted.

\section{DECLARATION OF INTERESTS}

This study was supported by a Brain Sciences award from the Medical Research Council (UK), and the Stanley Medical Research Institute. In the past 3 years $\mathrm{PJH}$ has received unrestricted educational grants from GlaxoSmithKline (GSK) and Merck, and honoraria for educational lectures or chairing scientific meetings from Bristol Myers Squibb,
GSK, Janssen, Lilly, Merck, Sanofi and Servier, and has been a scientific advisor to Curidium, Janssen, and Wyeth.

\section{REFERENCES}

Abdolmaleky HM, Cheng KH, Faraone SV, Wilcox M, Glatt SJ, Gao F et al (2006). Hypomethylation of MB-COMT promoter is a major risk factor for schizophrenia and bipolar disorder. Hum Mol Genet 15: 3132-3145.

Aleman A, Kahn RS, Selten JP (2003). Sex differences in the risk of schizophrenia-evidence from meta-analysis. Arch Gen Psychiatry 60: 565-571.

Andersen SL, Teicher MH (2000). Sex differences in dopamine receptors and their relevance to ADHD. Neurosci Biobehav Rev 24: 137-141.

Barnett JH, Heron J, Ring SM, Golding J, Goldman D, Xu K et al (2007a). Gender-specific effects of the catechol-O-methyltransferase $\mathrm{Val}(108) /(158)$ Met polymorphism on cognitive function in children. Am J Psychiatry 164: 142-149.

Barnett JH, Jones PB, Robbins TW, Mueller U (2007b). Effects of the catechol-O-ethyltransferase Val158Met polymorphism on executive function: a meta-analysis of the Wisconsin Card Sort Test in schizophrenia and healthy controls. Mol Psychiatry 12: 502-509.

Baron-Cohen S, Knickmeyer RC, Belmonte MK (2005). Sex differences in the brain: implications for explaining autism. Science 310: 819-823.

Becker JB (1999). Gender differences in dopaminergic function in striatum and nucleus accumbens. Pharmacol Biochem Behav 64: 803-812.

Beuten J, Payne T, Ma J, Li M (2006). Significant association of catechol-O-methyltransferase $(C O M T)$ haplotypes with nicotine dependence in male and female smokers of two ethnic populations. Neuropsychopharmacology 31: 675-684.

Bilder RM, Volavka J, Lachman HM, Grace AA (2004). The catechol-O-methyltransferase polymorphism: relations to the tonic-phasic dopamine hypothesis and neuropsychiatric phenotypes. Neuropsychopharmacology 29: 1943-1961.

Bjornerem A, Straume B, Midtby M, Fonnebo V, Sundsfjord J, Svartberg J et al (2004). Endogenous sex hormones in relation to age, sex, lifestyle factors, and chronic diseases in a general population: the Tromso Study. J Clin Endocrinol Metab 89: 6039-6047.

Boudikova B, Szumlanski C, Maidak B, Weinshilboum R (1990). Human liver catechol-O-methyltransferase pharmacogenetics. Clin Pharmacol Therap 48: 381-389.

Bray N, Buckland P, Williams N, Williams H, Norton N, Owen M et al (2003). A haplotype implicated in schizophrenia susceptibility associated with reduced COMT expression in human brain. Am J Hum Genet 73: 152-161.

Briggs MH, Briggs M (1973). Hormonal influences on erythrocyte catechol-O-methyl transferase activity in humans. Experientia 29: $278-280$.

Cahill L (2006). Why sex matters for neuroscience. Nat Rev Neurosci 7: 477-484.

Carroll ME, Lynch WJ, Roth ME, Morgan AD, Cosgrove KP (2004). Sex and estrogen influence drug abuse. Trends Pharmacol Sci 25: 273-279.

Chen JS, Lipska BK, Halim N, Ma QD, Matsumoto M, Melhem S et al (2004). Functional analysis of genetic variation in catechol$O$-methyltransferase $(C O M T)$ : effects on mRNA, protein, and enzyme activity in postmortem human brain. Am J Hum Genet 75: 807-821.

Cohn CK, Axelrod J (1971). The effect of estradiol on catechol-Omethyltransferase activity in rat liver. Life Sci 10: 1351-1354.

Collaer ML, Hines M (1995). Human behavioral sex differences: a role for gonadal hormones during early development? Psychol Bull 118: 55-107. 
Cosgrove KP, Mazure CM, Staley JK (2007). Evolving knowledge of sex differences in brain structure, function, and chemistry. Biol Psychiatry (in press; doi:10.1016/j.biopsych.2007.03.001).

Craddock N, Owen MJ, O'Donovan MC (2006). The catechol-Omethyl transferase (COMT) gene as a candidate for psychiatric phenotypes: evidence and lessons. Mol Psychiatry 11: 446-458.

Creveling CR (2003). The role of catechol-O-methyltransferase in the inactivation of catecholestrogen. Cell Mol Neurobiol 23: 289-291.

Crowley WR, O'Donohue TL, Jacobowitz DM (1978). Changes in catecholamine content in discrete brain nuclei during the estrous cycle of the rat. Brain Res 147: 315-326.

Cutter WJ, Daly EM, Robertson DMW, Chitnis XA, Van Amelsvoort TAMJ, Simmons A et al (2006). Influence of X chromosome and hormones on human brain development: a magnetic resonance imaging and proton magnetic resonance spectroscopy study of Turner syndrome. Biol Psychiatry 59: 273-283.

Dauvilliers Y, Neidhart E, Lecendreux M, Billiard M, Tafti M (2001). MAO-A and COMT polymorphisms and gene effects in narcolepsy. Mol Psychiatry 6: 367-372.

Davies W, Wilkinson LS (2006). It is not all hormones: alternative explanations for sexual differentiation of the brain. Brain Res 1126: $36-45$.

Dawling S, Roodi N, Mernaugh RL, Wang X, Parl FF (2001). Catechol-O-methyltransferase (COMT)-mediated metabolism of catechol estrogens: comparison of wild-type and variant COMT isoforms. Cancer Res 61: 6716-6722.

De Bellis J, Keshavan MS, Beers SR, Hall J, Frustaci K, Masalehdan A et al (2001). Sex differences in brain maturation during childhood and adolescence. Cereb Cortex 11: 552-557.

De Courten-Myers GM (1999). The human cerebral cortex: gender differences in structure and function. J Neuropathol Exp Neurol 58: $217-226$.

De Vries GJ (2004). Sex differences in adult and developing brain: compensation, compensation, compensation. Endocrinology 145: 1063-1068.

Dempster EL, Mill J, Craig IW, Collier DA (2006). The quantification of COMT mRNA in post mortem cerebellum tissue: diagnosis, genotype, methylation and expression. BMC Medical Genetics 7: 10.

Denys D, Van Nieuwerburgh F, Deforce D, Westenberg H (2006). Association between the dopamine $\mathrm{D} 2$ receptor TaqI A2 allele and low activity COMT allele with obsessive-compulsive disorder in males. Eur Neuropsychopharmacol 16: 446-450.

Domschke K, Deckert J, O'Donovan MC, Glatt SJ (2007). Metaanalysis of COMT val158met in panic disorder: ethnic heterogeneity and gender specificity. Am J Med Genet B Neuropsychiatr Genet 144B: 667-673.

Domschke K, Freitag CM, Kuhlenbaumer G, Schirmacher A, Sand $\mathrm{P}$, Nyhuis $\mathrm{P}$ et al (2004). Association of the functional V158M catechol-O-methyltransferase polymorphism with panic disorder in women. Int J Neuropsychopharmacol 7: 183-188.

Drabant EM, Hariri AR, Meyer-Lindenberg A, Munoz KE, Mattay VS, Kolachana BS et al (2006). Catechol-O-methyltransferase $\operatorname{val}(158)$ met genotype and neural mechanisms related to affective arousal and regulation. Arch Gen Psychiatry 63: 1396-1406.

Egan MF, Goldberg TE, Kolachana BS, Callicott JH, Mazzanti CM, Straub RE et al (2001). Effect of COMT Val ${ }^{108158}$ Met genotype on frontal lobe function and risk for schizophrenia. Proc Natl Acad Sci USA 98: 6917-6922.

Eley TC, Tahir E, Angleitner A, Harriss K, McClay J, Plomin R et al (2003). Association analysis of MAOA and COMT with neuroticism assessed by peers. Am J Medical Genet 120B: 90-96.

Enoch MA, Greenberg BD, Murphy DL, Goldman D (2001). Sexually dimorphic relationship of a $5-\mathrm{HT}_{2 \mathrm{~A}}$ promoter polymorphism with obsessive-compulsive disorder. Biol Psychiatry 49: $385-388$

Enoch MA, Waheed JF, Harris CR, Albaugh B, Goldman D (2006). Sex differences in the influence of COMT Val158Met on alcoholism and smoking in plains American Indians. Alcoholism Clin Exp Res 30: 399-406.

Enoch MA, Xu K, Ferro E, Harris CR, Goldman D (2003). Genetic origins of anxiety in women: a role for a functional catechol-Omethyltransferase polymorphism. Psychiatr Genet 13: 33-41.

Fahndrich E, Coper H, Christ W, Helmchen H, Muller-Oerlinghausen B, Pietzcker A (1980). Erythrocyte COMT-activity in patients with affective disorders. Acta Psychiatrica Scand 61: 427-437.

Fan JB, Zhang CS, Gu NF, Li XW, Sun WW, Huang HY et al (2005). Catechol-O-methyltransferase gene $\mathrm{Val} / \mathrm{Met}$ functional polymorphism and risk of schizophrenia: a large scale association study plus meta-analysis. Biol Psychiatry 57: 139-144.

Favis CF, Davis BF, Halaris AE (1977). Variations in the uptake of $\left[{ }^{3} \mathrm{H}\right] \sim$ dopamine during the estrous cycle. Life Sci 20: 1319-1332.

Fernandez-Ruiz JJ, Hernandez ML, De Miguel R, Ramos JA (1991). Nigrostriatal and mesolimbic dopaminergic activities were modified throughout the ovarian cycle of female rats. J Neural Transm Gen Sect 85: 223-229.

Fitzgerald GA, Hamilton CA, Jones DH, Reid JL (1980). Erythrocytes catechol-O-methyltransferase activity and indices of sympathetic activity in man. Clin Sci 58: 423-425.

Floderus Y, Wetterberg L (1981). The inheritance of human erythrocyte catechol-O-methyltransferase activity. Clin Genet 19: 392-393.

Fullerton J, Cubin M, Tiwari H, Wang C, Bomhra A, Davidson S et al (2003). Linkage analysis of extremely discordant and concordant sibling pairs identifies quantitative-trait loci that influence variation in the human personality trait neuroticism. Am J Hum Genet 72: 879-890.

Glatt SJ, Faraone SV, Tsuang MT (2003). Association between a functional catechol-O-methyltransferase gene polymorphism and schizophrenia: meta-analysis of case-control and familybased studies. Am J Psychiat 160: 469-476.

Gogos JA, Morgan M, Luine V, Santha M, Ogawa S, Pfaff D et al (1998). Catechol-O-methyltransferase-deficient mice exhibit sexually dimorphic changes in catecholamine levels and behavior. Proc Natl Acad Sci USA 95: 9991-9996.

Goldman-Rakic PS, Muly III EC, Williams GV (2000). D1 receptors in prefrontal cells and circuits. Brain Res Rev 31: 295-301.

Goldstein JM, Seidman LJ, Horton NJ, Makris N, Kennedy DN, Caviness Jr VS et al (2001). Normal sexual dimorphism of the adult human brain assessed by in vivo magnetic resonance imaging. Cereb Cortex 11: 490-497.

Goodman JE, Jensen LT, He P, Yager JD (2002). Characterization of human soluble high and low activity catechol-O-methyltransferase catalyzed catechol estrogen methylation. Pharmacogenetics 12: 517-528.

Gothelf D, Eliez S, Thompson T, Hinard C, Penniman L, Feinstein $\mathrm{C}$ et al (2005). COMT genotype predicts longitudinal cognitive decline and psychosis in 22q11.2 deletion syndrome. Nat Neurosci 8: 1500-1502.

Gur RC, Mozley LH, Mozley PD, Resnick SM, Karp JS, Alavi A et al (1995). Sex differences in regional cerebral glucose metabolism during a resting state. Science 267: 528-531.

Hines LM, Hoffman PL, Bhave S, Saba L, Kaiser A, Snell L et al (2006). A sex-specific role of type VII adenylyl cyclase in depression. J Neurosci 26: 12609-12619.

Holmans P, Zubenko G, Crowe R, DePaulo Jr JR, Scheftner W, Weissman $M$ et al (2004). Genomewide significant linkage to recurrent, early-onset major depressive disorder on chromosome 15q. Am J Hum Genet 74: 1154-1167.

Huotari M, Garcia-Horsman JA, Karayiorgou M, Gogos JA, Mannisto PT (2004). $d$-amphetamine responses in catechol-Omethyltransferase (COMT) disrupted mice. Psychopharmacology 172: $1-10$.

Huotari M, Gogos JA, Karayiorgou M, Koponen I, Forsberg M, Raasmaja A et al (2002a). Brain catecholamine metabolism in 
catechol-O-methyltransferase (COMT)-deficient mice. Eur J Neurosci 15: 246-256.

Huotari M, Santha M, Lucas LR, Karayiorgou M, Gogos JA, Mannisto PT (2002b). Effect of dopamine uptake inhibition on brain catecholamine levels and locomotion in catechol-O-methyltransferase-disrupted mice. J Pharmacol Exp Ther 303: 1309-1316.

Jiang H, Xie T, Ramsden DB, Ho SL (2003). Human catechol-Omethyltransferase down-regulation by estradiol. Neuropharmacology 45: 1011-1018.

Jori A, Cecchetti G (1973). Homovanillic acid levels in rat striatum during the oestrus cycle. J Endocrinol 58: 341-342.

Kaasinen V, Nogren K, Hietala J, Farde L, Rinne JO (2001). Sex differences in extrastriatal dopamine $\mathrm{D}_{2}$-like receptors in the human brain. Am J Psychiatry 158: 308-311.

Kaminsky Z, Wang SC, Petronis A (2006). Complex disease, gender and epigenetics. Ann Med 38: 530-544.

Karayiorgou M, Altemus M, Galke BL, Goldman D, Murphy D, Ott J et al (1997). Genotype determining low catechol-Omethyltransferase activity as a risk factor for obsessivecompulsive disorder. Proc Natl Acad Sci USA 94: 4572-4575.

Karayiorgou M, Sobin C, Blundell ML, Galke BL, Malinova L, Goldberg $\mathrm{P}$ et al (1999). Family-based association studies support a sexually dimorphic effect of COMT and MAOA on genetic susceptibility to obsessive-compulsive disorder. Biol Psychiatry 45: 1178-1189.

Karoum F, Chrapusta SJ, Egan MF (1994). 3-Methoxytyramine is the major metabolite of released dopamine in the rat frontal cortex: reassessment of the effects of antipsychotics on the dynamics of dopamine release and metabolism in the frontal cortex, nucleus accumbens, and striatum by a simple two pool model. J Neurochem 63: 972-979.

Kates WR, Antshel KM, AbdulSabur N, Colgan D, Funke B, Fremont W et al (2006). A gender-moderated effect of a functional COMT polymorphism on prefrontal brain morphology and function in velo-cardio-facial syndrome (22q11.2 deletion syndrome). Am J Med Genet 141B: 274-280.

Kelly SJ, Ostrowski NL, Wilson MA (1999). Gender differences in brain and behavior: hormonal and neural bases. Pharmacol Biochem Behav 64: 655-664.

Kempisty A, Mostowska A, Gфrska I, Luczak M, Czerski P, Szczepankiewicz A et al (2006). Association of $677 \mathrm{C}>\mathrm{T}$ polymorphism of methylenetetrahydrofolate reductase (MTHFR) gene with bipolar disorder and schizophrenia. Neurosci Lett 400: 267-271.

Kendler KS, Gatz M, Gardner CO, Pedersen NL (2006). A Swedish national twin study of lifetime major depression. Am J Psychiatry 163: 109-114.

Kim SJ, Kim YS, Kim SY, Lee HS, Kim CH (2006). An association study of catechol-O-methyltransferase and monoamine oxidase A polymorphisms and personality traits in Koreans. Neurosci Lett 401: 154-158.

Laakso A, Vilkman H, Bergman J, Haaparanta M, Solin O, Syvalahti E et al (2002). Sex differences in striatal presynaptic dopamine synthesis capacity in healthy subjects. Biol Psychiatry 52: 759-763.

Lachman HM, Papolos DF, Saito T, Yu YM, Szymlanksi C, Weinshilboum RM (1996). Human catechol-O-methyl-transferase polymorphism and its potential application to neuropsychiatric disorders. Pharmacogenetics 6: 243-250.

Lang UE, Bajbouj M, Sander T, Gallinat J (2007). Gender-dependent association of the functional catechol-O-methyltransferase Val158Met genotype with sensation seeking personality trait. Neuropsychopharmacology (in press; doi:10.1038/sj.npp.1301335).

Lensi P, Cassano GB, Correddu G, Ravagli S, Kunovac JL, Akiskal HS (1996). Obsessive-compulsive disorder. Familial-developmental history, symptomatology, comorbidity and course with special reference to gender-related differences. $\mathrm{Br} J$ Psychiatry 169: 101-107.
Lin PI, Vance JM, Pericak-Vance MA, Martin ER (2007). No gene is an island: the flip-flop phenomenon. Am J Hum Genet 80: 531-538.

Mannisto PT, Kaakkola S (1999). Catechol-O-methyltransferase (COMT): biochemistry, molecular biology, pharmacology, and clinical efficacy of the new selective COMT inhibitors. Pharmacol Rev 51: 593-628.

Mattay VS, Goldberg TE, Fera F, Hariri AR, Tessitore A, Egan MF et al (2003). Catechol- $O$-methyltransferase val158-met genotype and individual variation in the brain response to amphetamine. Proc Natl Acad Sci USA 100: 6186-6191.

Meyer-Lindenberg A, Nichols T, Callicott JH, Ding J, Kolachana B, Buckholtz J et al (2006). Impact of complex genetic variation in COMT on human brain function. Mol Psychiatry 11: 877-882.

Molero P, Ortuno F, Zalacain M, Patino-Garcia A (2007). Clinical involvement of catechol-O-methyltransferase polymorphisms in schizophrenia spectrum disorders: influence on the severity of psychotic symptoms and on the response to neuroleptic treatment. Pharmacogenomics J (in press doi:10.1038/sj.tpj.6500441).

Morissette M, Di Paolo T (1993). Sex and estrous cycle variations of rat striatal dopamine uptake sites. Neuroendocrinology 58: $16-22$.

Mozley LH, Gur RC, Mozley PD, Gur RE (2001). Striatal dopamine transporters and cognitive functioning in healthy men and women. Am J Psychiatry 158: 1492-1499.

Munro CA, McCaul ME, Wong DF, Oswald LM, Zhou Y, Brasic J et al (2006). Sex differences in striatal dopamine release in healthy adults. Biol Psychiatry 59: 966-974.

Murphy DGM, DeCarli C, McIntosh AR, Daly E, Mentis MJ, Pietrini $P$ et al (1996). Sex differences in human brain morphometry and metabolism: an in vivo quantitative magnetic resonance imaging and positron emission tomography study on the effect of aging. Arch Gen Psychiatry 53: 585-594.

Nackley A, Shabalina S, Tchivileva I, Satterfield K, Korchynskyi O, Makov S et al (2006). Human catechol-O-methyl-transferase haplotypes modulate protein expression by altering mRNA secondary structure. Science 314: 1930-1933.

Nash MW, Huezo-Diaz P, Williamson RJ, Sterne A, Purcell S, Hoda $\mathrm{F}$ et al (2004). Genome-wide linkage analysis of a composite index of neuroticism and mood-related scales in extreme selected sibships. Hum Mol Genet 13: 2173-2182.

Nestadt G, Lan T, Samuels J, Riddle M, Bienvenu III OJ, Liang KY et al (2000). Complex segregation analysis provides compelling evidence for a major gene underlying obsessive-compulsive disorder and for heterogeneity by sex. Am J Hum Genet 67: 1611-1616.

Nolan KA, Volavka J, Czobor P, Cseh A, Lachman HM, Saito T et al (2000). Suicidal behavior in patients with schizophrenia is related to COMT polymorphism. Psychiatr Genet 10: 117-124.

O'Hara R, Miller E, Liao CP, Way N, Lin XY, Hallmayer J (2006). COMT genotype, gender and cognition in community-dwelling, older adults. Neurosci Lett 409: 205-209.

Olsson CA, Anney RJ, Lotfi-Miri M, Byrnes GB, Williamson R, Patton GC (2005). Association between the COMT Val158Met polymorphism and propensity to anxiety in an Australian population-based longitudinal study of adolescent health. Psychiatr Genet 15: 109-115.

Ono H, Shirakawa O, Nushida H, Ueno Y, Maeda K (2004). Association between catechol-O-methyltransferase functional polymorphism and male suicide completers. Neuropsychopharmacology 29: 1374-1377.

O'Tuathaigh CM, Babovic D, O'Meara G, Clifford J, Croke D, Waddington J (2007). Susceptibility genes for schizophrenia: characterisation of mutant mouse models at the level of phenotypic behavior. Neurosci Biobehav Rev 31: 60-78.

Philippu G, Hoo JJ, Milech U, Argarwal DP, Schrappe O, Goedde HW (1981). Catechol- $O$-methyltransferase of erythrocytes in patients with endogenous psychoses. Psychiatry Res 4: 139-146. 
Piccinelli M, Wilkinson G (2000). Gender differences in depression - critical review. Br J Psychiatry 177: 486-492.

Pohjalainen T, Rinne JO, Nogren K, Syvalahti E, Hietala J (1998). Sex differences in the striatal dopamine $\mathrm{D}_{2}$ receptor binding characteristics in vivo. Am J Psychiatry 155: 768-773.

Pooley EC, Fineberg N, Harrison PJ (2007). The met ${ }^{158}$ allele of catechol-O-methyltransferase (COMT) is associated with obsessive-compulsive disorder in men: case-control study and meta-analysis. Mol Psychiatry 12: 556-561.

Poyurovsky M, Michaelovsky E, Frisch A, Knoll G, Amir I, Finkel B, Buniak F, Hermesh H, Weizman R (2005). COMT Vall58Met polymorphism in schizophrenia with obsessivecompulsive disorder: a case-control study. Neurosci Lett 389: 21-24.

Preece P, Cairns NJ (2003). Quantifying mRNA in postmortem human brain: influence of gender, age at death, postmortem interval, brain $\mathrm{pH}$, agonal state and inter-lobe mRNA variance. Mol Brain Res 118: 60-71.

Robinson DS, Sourkes TL, Nies A, Harris LS, Spector S, Bartlett DL et al (1977). Monoamine metabolism in human brain. Arch Gen Psychiatry 34: 89-92.

Rothe C, Koszycki D, Bradwejn J, King N, Deluca V, Tharmalingam $S$ et al (2006). Association of the Val158Met catchol-Omethyltransferase genetic polymorphism with panic disorder. Neuropsychopharmacology 31: 2237-2242.

Rubinow DR, Schmidt PJ (1996). Androgens, brain, and behavior. Am J Psychiatry 153: 974-984.

Rybakowski JK, Borkowska A, Czerski PM, Dmitrzak-Weglarz M, Skibinska M, Kapelski $P$ et al (2006). Performance on the Wisconsin Card Sorting Test in schizophrenia and genes of dopaminergic inactivation (COMT, DAT, NET). Psychiatry Res 143: 13-19.

Sazci A, Ergul E, Kucukali I, Kara I, Kaya G (2005). Association of the C677T and A1298C polymorphisms of methylenetetrahydrofolate reductase gene with schizophrenia: association is significant in men but not in women. Prog Neuropsychopharmacol Biol Psychiatry 29: 1113-1123.

Sazci A, Ergul E, Kucukali I, Kilic G, Kaya G, Kara I (2004). Catechol-O-methyltransferase gene Val108/158Met polymorphism and susceptibility to schizophrenia: association is more significant in women. Mol Brain Res 132: 51-56.

Seeman M (1997). Psychopathology in women and men: focus on female hormones. Am J Psychiatry 154: 1641-1647.

Shifman S, Bronstein M, Sternfeld M, Pisant A, Shalom A, Lev-Lehman E et al (2002). A highly significant association between a COMT haplotype and schizophrenia. Am J Hum Genet 71: $1296-1302$.

Shifman S, Bronstein M, Sternfeld M, Pisante A, Weizman A, Reznik I et al (2004). COMT: a common susceptibility gene in bipolar disorder and schizophrenia. Am J Med Genet Neuropsychiatr Genet 128B: 61-64.

Smolka MN, Schumann G, Wrase J, Grusser S, Flor H, Mann K et al (2005). Catechol-O-methyltransferase val $^{158}$ met genotype affects processing of emotional stimuli in the amygdala and prefrontal cortex. J Neurosci 25: 836-842.

Stein MB, Fallin MD, Schork NJ, Gelernter J (2005). COMT polymorphisms and anxiety related personality traits. Neuropsychopharmacology 30: 2092-2102.

Stone JL, Merriman B, Cantor RM, Yonan AL, Gilliam TC, Geschwind DH et al (2004). Evidence for sex-specific risk alleles in autism spectrum disorder. Am J Hum Genet 75: 1117-1123.

Sweet RA, Devlin B, Pollock BG, Sukonick DL, Kastango KB, Bacanu SA et al (2005). Catchol-O-methyltransferase haplotypes are associated with psychosis in Alzheimer disease. Mol Psychiatry 10: 1026-1036.
Tamminga CA (1997). Gender and schizophrenia. J Clin Psychiatry 58(Suppl15): 33-37.

Tunbridge E, Burnet PWJ, Sodhi MS, Harrison PJ (2004b). Catechol- $O$-methyltransferase (COMT) and proline dehydrogenase $(\mathrm{PRODH}) \mathrm{mRNAs}$ in the dorsolateral prefrontal cortex in schizophrenia, bipolar disorder, and major depression. Synapse 51: $112-118$.

Tunbridge EM, Bannerman DM, Sharp T, Harrison PJ (2004a). Catechol-O-methyltransferase inhibition improves set-shifting performance and elevates stimulated dopamine release in the rat prefrontal cortex. J Neurosci 24: 5331-5335.

Tunbridge EM, Harrison PJ, Warden D, Refsum H, Johnston C, Smith AD (2007c). Human plasma homocysteine levels are associated with the catechol-O-methyltransferase $\mathrm{Val}^{158} \mathrm{Met}$ polymorphism. Biol Psychiatry 61(Suppl): 191S.

Tunbridge EM, Harrison PJ, Weinberger DR (2006a). Catechol-Omethyltransferase, cognition, and psychosis: $\mathrm{Val}^{158} \mathrm{Met}$ and beyond. Biol Psychiatry 60: 141-151.

Tunbridge EM, Lane TA, Harrison PJ (2007b). Expression of multiple catechol-O-methyltransferase (COMT) mRNA variants in human brain. Am J Med Genet Neuropsychiatr Genet (E-pub 3 May 2007; doi:10.1002/ajmg.b.30539).

Tunbridge EM, Weickert CS, Kleinman JE, Herman MM, Chen J, Kolachana BS et al (2007a). Catechol-O-methyltransferase enzyme activity and protein expression in human prefrontal cortex across the postnatal lifespan. Cereb Cortex 17: 1206-1212.

Tunbridge EM, Weinberger DR, Harrison PJ (2006b). A novel protein isoform of catechol- $O$-methyltransferase (COMT): brain expression analysis in schizophrenia and bipolar disorder and effect of $\mathrm{Val}^{158}$ Met genotype. Mol Psychiatry 11: 116-117.

Vawter MP, Evans S, Choudary P, Tomita H, Meador-Woodruff J, Molnar M et al (2004). Gender-specific gene expression in postmortem human brain: localization to sex chromosomes. Neuropsychopharmacology 29: 373-384.

Weinberger DR, Egan MF, Bertolino A, Callicott JH, Mattay VS, Lipska BK et al (2001). Prefrontal neurons and the genetics of schizophrenia. Biol Psychiatry 50: 825-844.

Weiss LA, Pan L, Abney M, Ober C (2006). The sex-specific genetic architecture of quantitative traits in humans. Nat Genet 38: 218-222.

Williams-Gray C, Hamshire A, Robbins T, Owen A, Barker R (2007). Catechol-O-methyltransferase val ${ }^{158}$ met genotype influences frontoparietal activity during planning in patients with Parkinson's disease. J Neurosci 27: 4832-4838.

Woo J-M, Yoon K-S, Choi Y-H, Oh K-S, Lee Y-S, Yu B-H (2004). The association between panic disorder and the L/L genotype of catechol-O-methyltransferase. J Psychiatr Res 38: 365-370.

Worda C, Sator MO, Schneeberger C, Jantschev T, Ferlitsch K, Huber JC (2003). Influence of the catechol-O-methyltransferase (COMT) codon 158 polymorphism on estrogen levels in women. Hum Reprod 18: 262-266.

Xiao L, Becker JB (1994). Quantitative microdialysis determination of extracellular striatal dopamine concentration in male and female rats: effects of estrous cycle and gonadectomy. Neurosci Lett 180: 155-158.

Xie T, Ho SL, Ramsden D (1999). Characterization and implications of estrogenic down-regulation of human catechol-Omethyltransferase gene transcription. Mol Pharmacol 56: 31-38.

Zhu BT (2002). Catechol-O-methyltransferase (COMT)-mediated methylation metabolism of endogenous bioactive catechols and modulation by endobiotics and xenobiotics: importance in pathophysiology and pathogenesis. Curr Drug Metab 3: 321-329.

Zinkstok J, Schmitz N, van Amelsvoort T, de Win M, van den Brink W, Baas F et al (2006). The COMT val158met polymorphism and brain morphometry in healthy young adults. Neurosci Lett 405: 34-39. 